\title{
Risk factors for amyotrophic lateral sclerosis
}

This article was published in the following Dove Press journal:

Clinical Epidemiology

12 February 2015

Number of times this article has been viewed

\author{
Caroline Ingre' \\ Per M Roos ${ }^{2}$ \\ Fredrik Piehl' \\ Freya Kamel ${ }^{3}$ \\ Fang Fang ${ }^{4}$ \\ 'Department of Clinical \\ Neuroscience, ${ }^{2}$ Institute of \\ Environmental Medicine, Karolinska \\ Institutet, Stockholm, Sweden; \\ ${ }^{3}$ Epidemiology Branch, National \\ Institute of Environmental Health \\ Sciences, National Institutes of Health, \\ Research Triangle Park, NC, USA; \\ ${ }^{4}$ Department of Medical Epidemiology \\ and Biostatistics, Karolinska Institutet, \\ Stockholm, Sweden
}

Correspondence: Fang Fang

Department of Medical Epidemiology and Biostatistics, Karolinska Institutet, Box 28I, SE-17I 77 Stockholm, Sweden Tel +4685248 6131

Email fang.fang@ki.se
Abstract: Amyotrophic lateral sclerosis (ALS) is the most common motor neuron disease. It is typically fatal within 2-5 years of symptom onset. The incidence of ALS is largely uniform across most parts of the world, but an increasing ALS incidence during the last decades has been suggested. Although recent genetic studies have substantially improved our understanding of the causes of ALS, especially familial ALS, an important role of non-genetic factors in ALS is recognized and needs further study. In this review, we briefly discuss several major genetic contributors to ALS identified to date, followed by a more focused discussion on the most commonly examined non-genetic risk factors for ALS. We first review factors related to lifestyle choices, including smoking, intake of antioxidants, physical fitness, body mass index, and physical exercise, followed by factors related to occupational and environmental exposures, including electromagnetic fields, metals, pesticides, $\beta$-methylamino-L-alanine, and viral infection. Potential links between ALS and other medical conditions, including head trauma, metabolic diseases, cancer, and inflammatory diseases, are also discussed. Finally, we outline several future directions aiming to more efficiently examine the role of non-genetic risk factors in ALS.

Keywords: amyotrophic lateral sclerosis, risk factors, genetics, lifestyle, environment

\section{Introduction}

Amyotrophic lateral sclerosis (ALS) is an adult-onset, fatal neurodegenerative disorder, characterized by degeneration of both upper motor neurons in the primary motor cortex and lower motor neurons in the brainstem and spinal cord. Symptoms of ALS initially include muscle atrophy and weakness. Subsequently, spreading paralysis of the voluntary muscles, and eventually the respiratory muscles, often develops. ${ }^{1}$ Approximately $50 \%$ of patients with ALS die within 30 months of symptom onset, often from respiratory insufficiency, ${ }^{2,3}$ whereas about $10 \%$ of patients may survive for more than a decade. ${ }^{4}$

ALS has recently been recognized as a multi-system disorder rather than a disease limited to motor neurons. Some ALS patients may show extrapyramidal features such as tremor, rigidity, propulsion, and impaired postural reflexes. ${ }^{5,6}$ In about one quarter of ALS patients, the disease is associated with subtle cognitive deficits. In addition, $3 \%-5 \%$ of ALS patients are diagnosed with frontotemporal dementia (FTD), ${ }^{5}$ a dementia of non-Alzheimer's type with symptoms of behavioral changes, frontal executive deficit, and impaired handling of language. ${ }^{7}$ ALS and FTD are related conditions and overlap clinically, pathologically and genetically. ${ }^{8,9}$ The link between ALS and dementia may not be restricted to FTD though, as several epidemiological studies have shown a higher risk of dementia among families of ALS patients in general $^{10-13}$ 
and among families of ALS patients carrying an expanded hexanucleotide repeat in C9ORF72 specifically. ${ }^{12}$ Given the modest increment in risk observed for dementia among ALS families, and the lack of genotyping data for ALS in most previous studies, more research is needed before a firm conclusion regarding familial aggregation of ALS and dementia can be drawn.

About 10\%-15\% of ALS patients have a familial form of the disease, with at least two first-degree or second-degree relatives with ALS. ${ }^{14}$ If no family history is identified, the diagnosis is assumed to be sporadic. The incidence of sporadic ALS shows little variation in the Western countries, ranging from 1 to 2 per 100,000 person-years, ${ }^{15-18}$ with an estimated lifetime risk of 1 in $400 .{ }^{19}$ ALS is rare before the age of 40 years and increases exponentially with age thereafter. Mean age at onset is 58-63 years for sporadic ALS and 40-60 years for familial ALS, ${ }^{20-26}$ with a peak incidence in those aged 70-79 years. ${ }^{24-27}$ Men have a higher risk of ALS than women, leading to a male-to-female ratio of $1.2-1.5 .{ }^{28}$ During recent decades, an increasing incidence of or mortality from ALS has been reported in Sweden, ${ }^{27,29,30}$ Finland, ${ }^{31}$ Norway, ${ }^{32,33}$ France, ${ }^{34}$ the USA, ${ }^{35,36}$ and other countries, ${ }^{37-39}$ although an increase is less obvious in other studies. ${ }^{40-44}$ More research is needed to exclude alternative explanations for the suggested rise in incidence, including for example increasing awareness in the general public of ALS as a disease and better diagnosis of ALS in different neurologic settings.

Geographic foci of the Western Pacific form of ALS, mainly in Guam and the Kii Peninsula of Honshu Island, Japan, have been reported, with a prevalence 50-100 times higher than in other parts of the world. ${ }^{45,46}$ This form of ALS presents in three clinical forms, ie, ALS, atypical Parkinsonism with dementia, and dementia alone, known collectively as the ALS-Parkinson's dementia complex (ALS-PDC). The cause of these aggregations remains elusive, and a decreasing prevalence of ALS-PDC was noted recently. ${ }^{45}$

There is no cure for ALS to date. Riluzole, a presumed glutamate antagonist, is the only drug approved by the US Food and Drug Administration for the treatment of ALS, but the exact mechanism of action of riluzole is as yet unclear. It appears to prolong ALS survival by a few months on average, although when given at an early stage or to younger patients, it might prove more effective. ${ }^{47,48}$

\section{Risk factors for ALS}

A handful of factors have been proposed to be associated with ALS; however, the only established risk factors to date are older age, male sex, and a family history of ALS. ${ }^{49}$ In this review, we focus on several of the most frequently studied risk factors for ALS.

\section{Familial aggregation}

Family and twin studies are powerful tools for identifying a heritable component of different diseases. A disease is considered to aggregate in a family if the risk of developing the same disease is high among the relatives of an index patient compared with individuals unrelated to the index patient. Early case-control studies found that families of ALS patients had a 3 -fold ${ }^{50}$ to $>10$-fold ${ }^{51}$ risk of ALS. A Swedish twin study identified two of 26 monozygotic twin pairs with concordant ALS, but none in 51 dizygotic twin pairs, leading to a relative risk of 153 for monozygotic co-twins of ALS patients, compared with the general Swedish population. ${ }^{52}$ Pooling several twin registers from Sweden and the UK, the heritability for ALS is estimated at $61 \% .^{53}$

\section{Genetic risk factors}

The inheritance patterns of ALS vary depending on the mutation, although there is often a Mendelian pattern and high penetrance in familial ALS. The two major genetic contributors to ALS known to date are the C9ORF72 gene and the $S O D 1$ gene, but there are also a number of other genes associated with ALS, although not to the same extent (more information available at the Amyotrophic Lateral Sclerosis Online genetics database, http://alsod.iop.kcl.ac.uk/). Several excellent review articles have recently discussed ALS genetics in detail. ${ }^{54,55}$ In the present review, we focus on the C9ORF72, SOD1, and TARDBP genes, which are to date the most important genes identified in familial ALS cases.

\section{Chromosome 9 open reading frame 72}

The C9ORF72 gene, the function of which is as yet unknown, is located on chromosome 9. A mutation in this gene has been shown to cosegregate with both ALS and FTD in studies of American, European, and Japanese patients. ${ }^{56-59}$ The mutation is an expansion of a hexanucleotide repeat sequence, GGGGCC, in a non-coding part of the gene. In ALS patients, the number of repeats can be more than a thousand, in contrast with 2-30 repeats in control populations. ${ }^{56}$ Multiple studies have demonstrated that ALS and FTD phenotypes are associated with the $C 9 O R F 72$ GGGGCC hexanucleotide repeat expansion. ${ }^{57}$ The prevalence of the mutation is variable across countries; it is related to up to $40 \%$ of familial ALS in the USA and Europe, and up to 7\%-11\% of sporadic ALS. ${ }^{8,56,60}$ Recently, 20\% of ALS patients identified from the Kii Peninsula of Japan were found to carry this repeat expansion, 
compared with less than $2.5 \%$ in the rest of Japan, indicating that it may partially account for the high incidence of ALS-PDC in this geographic focus. ${ }^{61}$ The repeat expansion mutation in the C9ORF72 gene may result in a decreasing amount of functional C9ORF72 protein, and may therefore be a loss-of-function mutation. ${ }^{62}$ However, C9ORF72 may also be a toxic gain-of-function mutation; for example, the RNA transcribed from the repeated region might accumulate in the nucleus and interfere with cell function. ${ }^{56}$

\section{CuZn-superoxide dismutase}

Mutations in the SOD1 gene are found in 10\%-20\% of familial ALS cases and $1 \%-5 \%$ of sporadic ALS cases globally. ${ }^{63} \mathrm{CuZn}$-superoxide dismutase (SOD1) is one of three superoxide dismutase isoenzymes responsible for the conversion of free superoxide radicals to molecular oxygen and hydrogen peroxide. To date, more than 170 mutations of SOD1 have been identified in ALS. ${ }^{55,64}$ Most SOD1 mutations are inherited in a dominant manner, except for the D90A mutation, which is the most common SOD1 mutation worldwide and is inherited in both a dominant and a recessive manner. ${ }^{65,66}$ Animal studies have shown that transgenic expression of human SOD1 mutations in rodents results in a motor neuron disease phenotype, whereas knockout of the SOD1 gene in these rodents does not, ${ }^{67-69}$ suggesting that the pathogenicity of SOD1 mutations does not involve loss of function, but rather a gain of a toxic function. This toxicity may be due to the formation of aggregates caused by the instability of the protein..$^{70,71}$

\section{TAR DNA binding protein}

The TARDBP gene is located on chromosome 1 and codes for the DNA-binding and RNA-binding protein TDP-43. To date, 30 mutations of this gene have been found in about $5 \%$ of patients with familial ALS and $1 \%$ of patients with sporadic ALS. ${ }^{72-78}$ In healthy neurons, TDP-43 is located in the nucleus and functions as both a DNA-binding and an RNA-binding protein. TDP-43 is involved in transcription and RNA processing, including splicing and maintenance of mRNA stability, and transport of subcellular RNA. ${ }^{79-81}$ When mutated, TDP-43 is cleaved and abnormally phosphorylated, and accumulates in ubiquinated cytoplasmic inclusions in motor neurons of patients with familial ALS, sporadic ALS, or FTD., ${ }^{9,82}$

\section{Lifestyle risk factors Smoking}

According to an evidence-based medicine analysis, smoking is the only probable risk factor for ALS. ${ }^{49,83}$
Intriguingly, smoking may be a risk factor among women, especially post-menopausal women, ${ }^{84,85}$ although not among men. ${ }^{86}$ The controversy regarding the role of smoking in ALS appears to remain unsolved ${ }^{87,88}$ and is an interesting area for epidemiological studies of ALS. ${ }^{89}$

\section{Dietary factors}

The most investigated relationship between dietary factors and ALS is the inverse association between higher intake of antioxidants and a lower risk of ALS. For example, regular use of vitamin E supplements was associated with a lower risk of ALS, ${ }^{90}$ and a longer duration of vitamin E use was associated with a lower risk of ALS in a large study pooling individual data from five cohorts. ${ }^{91}$ Dietary intake of vitamin $\mathrm{E}$ was also associated with a lower risk of ALS in case-control studies from the Netherlands ${ }^{92}$ and Japan. ${ }^{93}$ These results were further corroborated by another cohort study that measured vitamin $\mathrm{E}$ serum levels directly. ${ }^{94}$ In other smaller studies, however, levels of vitamin E did not differ between ALS patients and controls, neither in the cerebrospinal fluid (CSF) ${ }^{95}$ nor in the serum ${ }^{95,96}$ samples. Further, high-dose vitamin E as an add-on therapy to riluzole in ALS did not extend survival, although improvement in the rate of deterioration of function was suggested for vitamin E. ${ }^{97}$ Another group of antioxidants associated with a lower risk of ALS is polyunsaturated fatty acids, ${ }^{92,98,99}$ which may modulate lipid metabolism, oxidative stress, and inflammatory processes. Evidence for the role of other dietary factors in ALS, including consumption of coffee ${ }^{100,101}$ and alcohol, ${ }^{102,103}$ is scant.

\section{Body mass index and physical fitness}

There is a strong clinical impression that ALS patients have a higher level of physical fitness and lower body mass index (BMI) than average. ${ }^{104}$ Whether there is an overrepresentation of higher physical fitness among presymptomatic ALS patients is not firmly established. However, based on a large sample of Swedish conscripts, one longitudinal study showed that higher physical fitness, but not muscle strength, measured at age 18 years was associated with a higher risk of ALS decades later. ${ }^{105}$ Low $\mathrm{BMI}$ and higher $\mathrm{BMI}$ reduction rate have been shown to be independent prognostic indicators for ALS after diagnosis. ${ }^{106-108}$ Longitudinal cohort studies further suggest that low premorbid BMI is associated with a higher risk of and greater mortality from ALS. ${ }^{109,110}$

\section{Athleticism, chronic traumatic encephalopathy, and physical exercise}

Historically, the most famous ALS patient was Lou Gehrig, the renowned US baseball player. Several studies have 
demonstrated increased risk of ALS among football or soccer players, ${ }^{111-114}$ other athletes, ${ }^{115}$ and individuals who engage in vigorous physical activity, ${ }^{116}$ but inconsistent results have also been reported. ${ }^{117-120}$ Strenuous physical activity, repeated head injuries, use of illicit performance-enhancing drugs, or chemicals used to treat football fields have all been discussed as potential explanations for such risk elevations. ${ }^{111,121}$ Chronic traumatic encephalopathy, a newly defined neurodegenerative disease, often resulting from repeated head injuries, has been proposed as the underlying reason or the "correct" diagnosis for ALS cases observed among professional athletes and perhaps also among military veterans. ${ }^{122}$ Different levels of physical exercise (professional versus recreational) may have very different biological effects on neurodegeneration. This is in line with previous findings of an increased risk of ALS among professional football players, ${ }^{11-114}$ although not among high school players. ${ }^{119}$ Similarly, a large European case-control study showed a 51\% lower risk of ALS for organized sport, but a 59\% higher risk of ALS for professional sport. ${ }^{123}$ Further efforts to disentangle the different exposure patterns involved in professional sports as compared with recreational sports will be needed to better understand these findings. Although the hypothesis that athleticism contributes to ALS is intriguing, caution should be exercised in interpreting these findings, given the fact that the vast majority are based on small numbers of ALS cases.

\section{Occupational and environmental risk factors \\ Occupations}

Workers in various occupations with seemingly disparate exposures have been reported to be potentially at altered risk of ALS, including athletes, carpenters, cockpit workers, construction workers, electrical workers, farm workers, hairdressers, house painters, laboratory technicians, leather workers, machine assemblers, medical service workers, military workers, nurses, power production plant workers, precision metal workers, programmers, rubber workers, shepherds, tobacco workers, veterinarians, and welders. ${ }^{124,125}$ These occupations potentially involve work exposures to chemicals, pesticides, metals, and electromagnetic fields (EMF). ${ }^{125-127}$ However, common denominators among these different occupations are not easily identified.

Military personnel are exposed to a battery of unique and potentially harmful factors, including physical and psychological exertion and trauma, transmissible agents (eg, viruses) and vaccines, toxic substances (eg, heavy metals and chemicals), and other environmental toxicants specific to particular deployment areas. A review article focusing on the potential links between military-related factors and ALS has been published recently, and concluded that although there is evidence suggesting a role of military service in ALS, it is too premature to draw a firm conclusion regarding a causal relationship. $^{128}$

\section{Electric occupation, electric shock, and electromagnetic field}

ALS has been associated with "electrical" occupations, ${ }^{129,130}$ especially welding. ${ }^{131}$ Magnetic fields, electrical fields, contact currents, microshocks, and both perceptible and imperceptible electric shocks all contribute to occupational exposure to extremely low frequency EMF. The reported association of ALS with EMF is generally weaker than that with electrical occupations. ${ }^{129,130}$ Evidence is not yet available to distinguish whether electric shocks or exposure to EMF underlies the association between electrical occupation and ALS. ${ }^{132-134} \mathrm{~A}$ meta-analysis suggested that there might be a slight but statistically significant increase in ALS risk among people with job descriptions related to relatively high levels of EMF exposure. ${ }^{135}$ However, studies using residential proximity to power lines as a proxy for EMF exposure have failed to support such a relationship. ${ }^{136,137}$ Different exposure levels investigated in studies of occupational, compared with residential, exposure to EMF may partly explain the different findings to date.

\section{Metals}

That lead may be a culprit in ALS etiology is a long-standing hypothesis. Previous studies have mostly supported this relationship, relying in general on indirect measures of lead exposure. ${ }^{15,138-148}$ Lead levels in both blood and bone were found to be associated with ALS, ${ }^{147,148}$ although others found only an association for blood and not bone. ${ }^{149}$ Blood lead levels may reflect current environmental lead exposure and may also reflect mobilization of lead from bone. ${ }^{150}$ Lead toxicokinetics and bone metabolism may therefore modify the lead-ALS association. A recent case-control study observed that blood lead levels were high among ALS cases compared with controls, even after careful adjustment for bone turnover status and a polymorphism affecting lead toxicokinetics. ${ }^{151}$

The neurotoxic properties of manganese are well known. ${ }^{152}$ Manganese crosses barrier systems at the choroid plexus and accumulates in the central nervous system, with a longer half-life in nervous tissue. Welders exposed to manganese demonstrate motor impairments in general ${ }^{153}$ and impaired fine motor skills specifically. ${ }^{154}$ Manganese concentrations in CSF samples of ALS patients were significantly elevated 
(median $5.67 \mu \mathrm{g} / \mathrm{L}$ ) compared with healthy controls (median $2.08 \mu \mathrm{g} / \mathrm{L}) .{ }^{155}$ Furthermore, manganese concentrations were higher in the CSF than in the plasma of ALS patients, suggesting a transport of manganese into the central nervous system in ALS. ${ }^{155}$

Iron serves as a cofactor for regulatory enzymes in the electron transport chain in the mitochondria. Brain iron content increases with age, and iron accumulation has been noted in other neurodegenerative disorders. ${ }^{156}$ Among ALS patients, increased iron concentration has been reported in the ventral spinal cord ${ }^{157}$ and in the motor cortex, especially the hand knob region, presumably corresponding to the small hand muscle weakness seen in these patients. ${ }^{158}$

The potential role of the metalloid selenium has been investigated in endemic clusters of ALS in selenium-rich regions of South Dakota ${ }^{159}$ and in Italy. ${ }^{160}$ Recent studies of selenium in the CSF of patients in Italy have shown elevated selenite concentrations, maybe related to elevated selenium exposure via drinking water. ${ }^{161}$ To what extent these findings may be generalizable to other population remains to be elucidated.

Other metals with potential relevance for ALS are copper, aluminum, arsenic, cadmium, cobalt, zinc, vanadium, and uranium, all of which have been found in significantly elevated concentrations in the CSF of ALS patients when compared with healthy controls. ${ }^{162}$

\section{Pesticides}

Pesticides are in widespread use worldwide and can be measured in various concentrations in air, food, and water. An association between pesticide use and ALS has been explicitly evaluated and suggested in previous studies, ${ }^{139-141,146,163-166}$ including two recent studies from India ${ }^{167}$ and the USA (organochlorine compounds, pyrethroids, herbicides, and fumigants specifically). ${ }^{168}$ In meta-analyses, pesticide use was found to be significantly associated with a higher risk of ALS, ${ }^{168,169}$ although the latter study ${ }^{169}$ suggested a malespecific association.

\section{$\beta$-methylamino-L-alanine}

Exposure to $\beta$-methylamino-L-alanine (BMAA), an atypical amino acid, has been proposed to explain the high incidence of ALS-PDC in the western Pacific. ${ }^{45}$ BMAA was originally believed to be produced on Guam and elsewhere by a local Micronesian plant, Cycas micronesica; more recently, it was recognized that BMAA does not originate from the plant itself but rather from cyanobacteria. ${ }^{170}$ Further, cyanobacteria apparently produce BMAA in settings outside Guam. ${ }^{170}$
In one study, BMAA was higher in the brain and spinal cord tissues of patients with ALS or Alzheimer's disease than in healthy controls or patients with other diseases. ${ }^{171}$ A recent study has demonstrated that BMAA bioaccumulates in the Baltic Sea ecosystem and identified pathways for human exposure. ${ }^{172}$ Neurotoxins other than BMAA produced by cyanobacteria may also contribute to neurodegeneration. ${ }^{173}$

\section{Viruses}

Previous viral infection has also been considered as a potential risk factor for ALS. For example, a role of enteroviral infections in ALS has been hypothesized since neurons in the anterior horn of the spinal cord are the target cells both in ALS and enteroviral infections, including poliomyelitis. ${ }^{174}$ Using reverse transcriptase (RT) in situ polymerase chain reaction, enterovirus RNA was detected in motor neurons of the anterior horn of patients with ALS. ${ }^{175}$ Exposure to other viruses may also be important. Human herpesvirus (HHV)-6 seropositivity was associated with a more than threefold risk of ALS, and HHV-8 seropositivity with a more than eightfold risk. ${ }^{176}$ Retroviruses, such as human immunodeficiency virus and human T-cell lymphotrophic virus-1, caused motor neuron syndromes. ${ }^{177}$ Some as yet unidentified retrovirus might also be a risk factor for ALS, because a mouse retrovirus (murine leukemia virus) causes both a lower motor neuron syndrome and leukemia/lymphoma. ${ }^{178}$ A more broad measure of retroviral infection, ie, serum activity of reverse transcriptase (an enzyme characterizing retroviral infections), was similar among ALS patients and their blood relatives, but lower among their spouses, who had levels similar to that of other non-blood-related controls. ${ }^{179}$ More recent studies of the expression of human endogenous retroviral sequences have revealed significantly increased expression of human endogenous retro virus type K (HERV-K), one of the two most studied human endogenous retroviruses given its complete open reading frame and ability to form viruslike particles, in the serum, muscle, and post mortem brain tissue of ALS patients. ${ }^{180-183}$

\section{Medical conditions}

The general belief that ALS is a complex multifactorial disease has suggested the importance of studying the relationship between ALS and other medical conditions, which may share environmental risk factors or a genetic predisposition with ALS. In this review, we focus our discussion on the potential roles of head trauma, metabolic diseases, cancer, and neuroinflammation in ALS. 


\section{Head trauma}

Early case-control studies reported a significant association between history of head trauma and ALS. ${ }^{184}$ Aiming to rule out the possibilities of recall bias and reverse causality (ie, trauma as a result, rather than a cause, of ALS), later studies generally used more objective assessment of head trauma history and excluded traumas experienced during the years immediately before the diagnosis of ALS. ${ }^{185,186}$ Severe head traumas that were hospitalized were not associated with a higher risk of ALS in Sweden. ${ }^{186}$ A possible association of ALS with milder head traumas, perhaps specifically with repeatedly experienced mild traumas, has not been thoroughly addressed.

\section{Metabolic diseases}

An interest in the relationship between metabolic disorders and ALS arose after the observation that ALS patients are hypermetabolic. ${ }^{187}$ Previous studies suggested that type 2 diabetes is associated with a lower risk of ALS, ${ }^{188}$ while type 1 diabetes, as well as some other autoimmune diseases, might instead be risk factors for ALS. ${ }^{189}$ In a recent study, we confirmed an inverse association between type 2 diabetes and risk of ALS, and found that type 1 diabetes was indeed associated with a threefold risk of ALS. ${ }^{190}$ Medications used for treatments of metabolic disorders, independently of the underlying disorders, may also be associated with the development of ALS. However, the evidence gathered to date is inconclusive regarding the relationship between use of statins ${ }^{191}$ and the risk or progression of ALS, and between the antidiabetic drug, pioglitazone, and progression of ALS. ${ }^{192}$ However, these findings are not surprising given the complexity of their properties. Pioglitazone, for example, is both antioxidant and anti-inflammatory and may protect against neurodegeneration, but it is also antidiabetic and antidyslipidemic and may therefore be detrimental for ALS, if the emerging evidence of a potentially protective effect of obesity and type 2 diabetes with regard to ALS proves true.

\section{Cancer}

Although the incidence of neurodegenerative diseases and of cancer increases in older adults, these two groups of diseases are characterized by largely opposing cellular behavior, ie, premature cell death in neurodegeneration and resistance to cell death in carcinogenesis. ${ }^{193}$ A potential inverse relationship between neurodegenerative diseases (eg, Alzheimer's disease and Parkinson's disease) and cancer has been observed, and is plausible for the reasons discussed. ${ }^{194}$ Based on clinical case series or case reports, earlier studies suggested a positive association between ALS and cancer. ${ }^{195-197}$ Most epidemiological studies have refuted such a link in general, ${ }^{198-201}$ except for melanoma. ${ }^{199,201-203}$ The most recent, large-scale, prospective cohort studies have similarly refuted a positive association between cancer, including melanoma, and ALS. ${ }^{204,205}$

\section{Neuroinflammation}

Since the earliest pathological changes in ALS appear to occur in axons, dendrites, and synapses, ${ }^{206}$ studies of the relationship between inflammatory conditions around the motor unit and ALS may shed light on the pathological development of ALS. Clinically, early symptoms of ALS can be difficult to differentiate from symptoms of other inflammatory neuromuscular diseases such as myositis, myasthenia gravis, Guillain-Barré syndrome, and multiple sclerosis. Due to the difficulties in determining the correct diagnosis, misdiagnosis may be an explanation for any higher-than-expected co-occurrence of ALS and inflammatory diseases. ${ }^{207}$ Interestingly, ALS and multiple sclerosis were reported to co-occur in individuals with the C9ORF72 repeat expansion, suggesting some biological overlaps between ALS and autoimmune/inflammatory diseases. ${ }^{208}$ However, apart from several reports of cases diagnosed with both ALS and with some of the conditions above, few studies have addressed this issue.

\section{Interactions between genetic and non-genetic factors}

Intriguingly, studies have shown that even subjects carrying highly penetrant mutations do not always develop ALS. For example, based on a pair of monozygotic twins with a similar methylation level and repeat size of C9ORF72 expansion but who were discordant for ALS, a recent study highlights the importance of non-genetic modifiers in the development of ALS. ${ }^{209}$ In that study, the co-twin who developed ALS had a history of both smoking and head trauma, whereas the non-ALS co-twin had neither exposure. ${ }^{209}$ Insight gained from studying gene-environment interactions has furthered our understanding of disease etiologies, for example, the interaction between the $A P O E$ gene and traumatic brain injury in Alzheimer's disease, ${ }^{210}$ the $H L A$ gene and smoking in multiple sclerosis, ${ }^{211}$ and the $\alpha$-synuclein Repl gene and Parkinson's disease. ${ }^{212}$

\section{Future developments}

Identification of risk factors, especially non-genetic factors, for ALS has proven difficult, and likely reflects the complexity of the disease. Below, we briefly discuss reasons that in our opinion are the most important for the lack of success, and outline strategies to circumvent these obstacles. 
Arguably, the most pressing unmet need in ALS research is to better classify subtypes of ALS, in terms of clinical presentation of symptoms, survival profile, genetic background, and underlying pathology. ${ }^{213,214}$ The lack of such information is likely to contribute to the inconclusive findings to date regarding risk factors and underlying mechanisms for ALS, as well as the lack of success in various clinical trials for ALS.

Up until now, different risk factors have mainly been studied independently of one another. An alternative strategy would be to study different prevailing hypotheses in concert, rather than individually. Such a strategy might prove more informative, perhaps enabling identification of common pathophysiological pathways leading to motor neuron degeneration. One approach would be intensive evaluation of multiple risk factors within clinical and population-based case-control studies of ALS, where many different types of information could be collected at the time of recruitment. Another strategy might be to study a population at high risk for ALS because of the presence of one or more risk factors, such as family members of ALS patients, and to evaluate other risk factors within this population. If information could be collected longitudinally and repeatedly in such a setting, it would have substantial potential to further our understanding of the synergistic activities of different factors in leading to a higher risk of neurodegeneration.

Even for an individual risk factor, a more systemic approach may be needed to understand the mechanisms linking the factor to ALS. In the case of lead, for example, an effort should be made to incorporate measurements of exposure in different body compartments, including blood, CSF, bone, and muscle. Contrasting lead levels in different compartments provides a better understanding of the dynamics of lead metabolism and the permeability of different barriers between the peripheral circulation and the central nervous system, including the bloodbrain barrier and the blood-CSF barrier. ${ }^{215}$ Given the fact that bone is by far the largest storage compartment for lead, bone metabolism parameters, such as bone resorption and bone formation, will be important to understand whether and how lead is associated with the risk of ALS.

Although many non-genetic risk factors have been described for ALS, their interaction with different genetic backgrounds relevant to ALS remains elusive. This is likely due to the fact that ALS is a rare disease and single-center studies usually lack sufficient statistical power to test for gene-environment interactions. The past decade and the coming years are an important time for ALS genetics, as several international consortia are being developed with largescale and deep screening at both the genetic and epigenetic levels. ${ }^{89}$ Many of these consortia also plan to collect detailed information on environmental and lifestyle risk factors, aiming to uncover important gene-environment interactions in the etiopathogenesis of ALS. The importance of ensuring representativeness of the enrolled ALS patients, collecting uniform, standardized data across multiple countries, ALS registries, or clinics remains a challenge for such studies.

Finally, while the majority of the previous case-control studies of ALS have primarily used one specific group of controls, be it population-based controls, controls with other diseases, or convenience controls (ie, family members, friends, neighbors), it is perhaps advisable to recruit multiple groups of controls in future case-control studies of ALS. Enrollment of relatives (including blood-related and non-blood-related) of ALS patients and individuals with other neurological or neurodegenerative diseases, as well as population-based controls would be preferable, wherever it is possible and affordable.

\section{Conclusion}

Over the last two decades, a great deal of new knowledge has been gathered on ALS, especially in terms of its underlying genetics and potential mechanisms implied by these genetic findings. In contrast, although we generally agree that there is substantial impact of non-genetic factors on the etiology of ALS, so far little progress has been made in identifying these factors with some degree of certainty. An improved knowledge of non-genetic risk factors for ALS, hand-in-hand with our increasing knowledge of ALS genetics, should prove more fruitful in deciphering the causes of this devastating disease and eventually providing a cure.

\section{Acknowledgments}

The study was supported by the Swedish Research Council, the Swedish Society of Medical Research, and the Karolinska Institutet.

\section{Disclosure}

The authors report no conflicts of interest in this work.

\section{References}

1. Wijesekera LC, Leigh PN. Amyotrophic lateral sclerosis. Orphanet $J$ Rare Dis. 2009;4:3.

2. Talbot K. Motor neuron disease: the bare essentials. Pract Neurol. 2009;9(5):303-309.

3. del Aguila MA, Longstreth WT Jr, McGuire V, Koepsell TD, van Belle G. Prognosis in amyotrophic lateral sclerosis: a population-based study. Neurology. 2003;60(5):813-819.

4. Forsgren L, Almay BG, Holmgren G, Wall S. Epidemiology of motor neuron disease in northern Sweden. Acta Neurol Scand. 1983;68(1): $20-29$. 
5. Al-Chalabi A, Leigh PN. Recent advances in amyotrophic lateral sclerosis. Curr Opin Neurol. 2000;13(4):397-405.

6. Desai J, Swash M. Extrapyramidal involvement in amyotrophic lateral sclerosis: backward falls and retropulsion. J Neurol Neurosurg Psychiatry. 1999;67(2):214-216.

7. Neary D, Snowden JS, Gustafson L, et al. Frontotemporal lobar degeneration: a consensus on clinical diagnostic criteria. Neurology. 1998;51(6):1546-1554.

8. Renton AE, Majounie E, Waite A, et al. A hexanucleotide repeat expansion in C9ORF72 is the cause of chromosome 9p21-linked ALS-FTD. Neuron. 2011;72(2):257-268.

9. Neumann M, Sampathu DM, Kwong LK, et al. Ubiquitinated TDP-43 in frontotemporal lobar degeneration and amyotrophic lateral sclerosis. Science. 2006;314(5796):130-133.

10. Majoor-Krakauer D, Ottman R, Johnson WG, Rowland LP. Familial aggregation of amyotrophic lateral sclerosis, dementia, and Parkinson's disease: evidence of shared genetic susceptibility. Neurology. 1994; 44(10):1872-1877.

11. Huisman MH, de Jong SW, Verwijs MC, et al. Family history of neurodegenerative and vascular diseases in ALS: a population-based study. Neurology. 2011;77(14):1363-1369.

12. Byrne S, Heverin M, Elamin M, et al. Aggregation of neurologic and neuropsychiatric disease in amyotrophic lateral sclerosis kindreds: a population-based case-control cohort study of familial and sporadic amyotrophic lateral sclerosis. Ann Neurol. 2013;74(5): 699-708.

13. Fallis BA, Hardiman O. Aggregation of neurodegenerative disease in ALS kindreds. Amyotroph Lateral Scler. 2009;10(2):95-98.

14. Byrne S, Bede P, Elamin M, et al. Proposed criteria for familial amyotrophic lateral sclerosis. Amyotroph Lateral Scler. 2011;12(3): $157-159$.

15. McGuire V, Longstreth WT Jr, Koepsell TD, van Belle G. Incidence of amyotrophic lateral sclerosis in three counties in western Washington State. Neurology. 1996;47(2):571-573.

16. Traynor BJ, Codd MB, Corr B, Forde C, Frost E, Hardiman O. Incidence and prevalence of ALS in Ireland, 1995-1997: a population-based study. Neurology. 1999;52(3):504-509.

17. Beghi E, Millul A, Micheli A, Vitelli E, Logroscino G. Incidence of ALS in Lombardy, Italy. Neurology. 2007;68(2):141-145.

18. Vazquez MC, Ketzoian C, Legnani C, et al. Incidence and prevalence of amyotrophic lateral sclerosis in Uruguay: a population-based study. Neuroepidemiology. 2008;30(2):105-111.

19. Johnston CA, Stanton BR, Turner MR, et al. Amyotrophic lateral sclerosis in an urban setting: a population based study of inner city London. J Neurol. 2006;253(12):1642-1643.

20. Testa D, Lovati R, Ferrarini M, Salmoiraghi F, Filippini G. Survival of 793 patients with amyotrophic lateral sclerosis diagnosed over a 28-year period. Amyotroph Lateral Scler Other Motor Neuron Disord. 2004;5(4):208-212.

21. Logroscino G, Traynor BJ, Hardiman O, et al. Incidence of amyotrophic lateral sclerosis in Europe. J Neurol Neurosurg Psychiatry. 2010;81(4): 385-390.

22. Cudkowicz ME, McKenna-Yasek D, Sapp PE, et al. Epidemiology of mutations in superoxide dismutase in amyotrophic lateral sclerosis. Ann Neurol. 1997;41(2):210-221.

23. Juneja T, Pericak-Vance MA, Laing NG, Dave S, Siddique T. Prognosis in familial amyotrophic lateral sclerosis: progression and survival in patients with glu100gly and ala4val mutations in $\mathrm{Cu}, \mathrm{Zn}$ superoxide dismutase. Neurology. 1997;48(1):55-57.

24. Huisman MH, de Jong SW, van Doormaal PT, et al. Population based epidemiology of amyotrophic lateral sclerosis using capturerecapture methodology. J Neurol Neurosurg Psychiatry. 2011;82(10): $1165-1170$

25. Uenal $\mathrm{H}$, Rosenbohm A, Kufeldt J, et al. Incidence and geographical variation of amyotrophic lateral sclerosis (ALS) in Southern Germany - completeness of the ALS registry Swabia. PLoS One. 2014;9(4):e93932.
26. Piemonte and Valle d'Aosta Register for Amyotrophic Lateral Sclerosis (PARALS). Incidence of ALS in Italy: evidence for a uniform frequency in Western countries. Neurology. 2001;56(2):239-244.

27. Fang F, Valdimarsdottir U, Bellocco R, et al. Amyotrophic lateral sclerosis in Sweden, 1991-2005. Arch Neurol. 2009;66(4):515-519.

28. Manjaly ZR, Scott KM, Abhinav K, et al. The sex ratio in amyotrophic lateral sclerosis: a population based study. Amyotroph Lateral Scler. 2010;11(5):439-442.

29. Landtblom AM, Riise T, Boiko A, Soderfeldt B. Distribution of multiple sclerosis in Sweden based on mortality and disability compensation statistics. Neuroepidemiology. 2002;21(4):167-179.

30. Neilson S, Gunnarsson LG, Robinson I. Rising mortality from motor neurone disease in Sweden 1961-1990: the relative role of increased population life expectancy and environmental factors. Acta Neurol Scand. 1994;90(3):150-159.

31. Maasilta P, Jokelainen M, Loytonen M, Sabel CE, Gatrell AC. Mortality from amyotrophic lateral sclerosis in Finland, 1986-1995. Acta Neurol Scand. 2001;104(4):232-235.

32. Seljeseth YM, Vollset SE, Tysnes OB. Increasing mortality from amyotrophic lateral sclerosis in Norway? Neurology. 2000;55(9): 1262-1266.

33. Neilson S, Robinson I, Nymoen EH. Longitudinal analysis of amyotrophic lateral sclerosis mortality in Norway, 1966-1989: evidence for a susceptible subpopulation. J Neurol Sci. 1994;122(2):148-154.

34. Neilson S, Robinson I, Alperovitch A. Rising amyotrophic lateral sclerosis mortality in France 1968-1990: increased life expectancy and inter-disease competition as an explanation. J Neurol. 1994;241(7): 448-455.

35. Stallones L, Kasarskis EJ, Stipanowich C, Snider G. Secular trends in mortality rates from motor neuron disease in Kentucky 1964-1984. Neuroepidemiology. 1989;8(2):68-78.

36. Riggs JE. Longitudinal Gompertzian analysis of amyotrophic lateral sclerosis mortality in the US, 1977-1986: evidence for an inherently susceptible population subset. Mech Ageing Dev. 1990;55(3): 207-220.

37. Murphy M, Quinn S, Young J, Parkin P, Taylor B. Increasing incidence of ALS in Canterbury, New Zealand: a 22-year study. Neurology. 2008;71(23):1889-1895.

38. Govoni V, Granieri E, Fallica E, Casetta I. Amyotrophic lateral sclerosis, rural environment and agricultural work in the Local Health District of Ferrara, Italy, in the years 1964-1998. J Neurol. 2005;252(11): $1322-1327$.

39. Cima V, Logroscino G, D'Ascenzo C, et al. Epidemiology of ALS in Padova district, Italy, from 1992 to 2005. Eur J Neurol. 2009;16(8): 920-924.

40. Veiga-Cabo J, Almazan-Isla J, Sendra-Gutierrez JM, de Pedro-Cuesta J. Differential features of motor neuron disease mortality in Spain. Int J Epidemiol. 1997;26(5):1024-1032.

41. Mandrioli J, Faglioni P, Merelli E, Sola P. The epidemiology of ALS in Modena, Italy. Neurology. 2003;60(4):683-689.

42. Kihira T, Yoshida S, Hironishi M, Miwa H, Okamato K, Kondo T. Changes in the incidence of amyotrophic lateral sclerosis in Wakayama, Japan. Amyotroph Lateral Scler Other Motor Neuron Disord. 2005;6(3): $155-163$.

43. Okamoto K, Kobashi G, Washio M, et al. Descriptive epidemiology of amyotrophic lateral sclerosis in Japan, 1995-2001. J Epidemiol. 2005;15(1):20-23.

44. Sejvar JJ, Holman RC, Bresee JS, Kochanek KD, Schonberger LB. Amyotrophic lateral sclerosis mortality in the United States, 1979-2001. Neuroepidemiology. 2005;25(3):144-152.

45. Plato CC, Garruto RM, Galasko D, et al. Amyotrophic lateral sclerosis and parkinsonism-dementia complex of Guam: changing incidence rates during the past 60 years. Am J Epidemiol. 2003;157(2):149-157.

46. Kuzuhara S, Kokubo Y, Sasaki R, et al. Familial amyotrophic lateral sclerosis and parkinsonism-dementia complex of the Kii Peninsula of Japan: clinical and neuropathological study and tau analysis. Ann Neurol. 2001;49(4):501-511. 
47. Bensimon G, Lacomblez L, Meininger V. A controlled trial of riluzole in amyotrophic lateral sclerosis. ALS/Riluzole Study Group. $N$ Engl J Med. 1994;330(9):585-591.

48. Lacomblez L, Bensimon G, Leigh PN, Guillet P, Meininger V. Dose-ranging study of riluzole in amyotrophic lateral sclerosis. Amyotrophic Lateral Sclerosis/Riluzole Study Group II. Lancet. 1996;347(9013):1425-1431.

49. Armon C. An evidence-based medicine approach to the evaluation of the role of exogenous risk factors in sporadic amyotrophic lateral sclerosis. Neuroepidemiology. 2003;22(4):217-228.

50. Cruz DC, Nelson LM, McGuire V, Longstreth WT Jr. Physical trauma and family history of neurodegenerative diseases in amyotrophic lateral sclerosis: a population-based case-control study. Neuroepidemiology. 1999;18(2):101-110.

51. Kamel F, Umbach DM, Munsat TL, Shefner JM, Sandler DP. Association of cigarette smoking with amyotrophic lateral sclerosis. Neuroepidemiology. 1999;18(4):194-202.

52. Fang F, Kamel F, Lichtenstein P, et al. Familial aggregation of amyotrophic lateral sclerosis. Ann Neurol. 2009;66(1):94-99.

53. Al-Chalabi A, Fang F, Hanby MF, et al. An estimate of amyotrophic lateral sclerosis heritability using twin data. J Neurol Neurosurg Psychiatry. 2010;81(12):1324-1326.

54. Renton AE, Chio A, Traynor BJ. State of play in amyotrophic lateral sclerosis genetics. Nat Neurosci. 2014;17(1):17-23.

55. Andersen PM, Al-Chalabi A. Clinical genetics of amyotrophic lateral sclerosis: what do we really know? Nat Rev Neurol. 2011;7(11): 603-615.

56. Dejesus-Hernandez M, Mackenzie IR, Boeve BF, et al. Expanded GGGGCC hexanucleotide repeat in noncoding region of C9ORF72 causes chromosome 9p-linked FTD and ALS. Neuron. 2011;72(2):245-256.

57. Renton AE, Majounie E, Waite A, et al. A hexanucleotide repeat expansion in C9ORF72 is the cause of chromosome 9p21-linked ALS-FTD. Neuron. 2011;72(2):257-268.

58. Gijselinck I, Van Langenhove T, van der Zee J, et al. A C9orf72 promoter repeat expansion in a Flanders-Belgian cohort with disorders of the frontotemporal lobar degeneration-amyotrophic lateral sclerosis spectrum: a gene identification study. Lancet Neurol. 2012;11(1): 54-65.

59. Millecamps S, Boillée S, Le Ber I, et al. Phenotype difference between ALS patients with expanded repeats in C9ORF72 and patients with mutations in other ALS-related genes. J Med Genet. 2012;49(4): 258-263.

60. Gijselinck I, Van Langenhove T, van der Zee J, et al. A C9orf72 promoter repeat expansion in a Flanders-Belgian cohort with disorders of the frontotemporal lobar degeneration-amyotrophic lateral sclerosis spectrum: a gene identification study. Lancet Neurol. 2012;11(1): 54-65.

61. Ishiura H, Takahashi Y, Mitsui J, et al. C9ORF72 repeat expansion in amyotrophic lateral sclerosis in the Kii peninsula of Japan. Arch Neurol. 2012;69(9):1154-1158.

62. Belzil VV, Bauer PO, Prudencio M, et al. Reduced C9orf72 gene expression in c9FTD/ALS is caused by histone trimethylation, an epigenetic event detectable in blood. Acta Neuropathol. 2013;126(6):895-905.

63. Andersen PM, Nilsson P, Forsgren L, Marklund SL. CuZn-superoxide dismutase, extracellular superoxide dismutase, and glutathione peroxidase in blood from individuals homozygous for Asp90Ala CuZusuperoxide dismutase mutation. J Neurochem. 1998;70(2):715-720.

64. Felbecker A, Camu W, Valdmanis PN, et al. Four familial ALS pedigrees discordant for two SOD1 mutations: are all SOD1 mutations pathogenic? J Neurol Neurosurg Psychiatry. 2010;81(5):572-577.

65. Robberecht W, Aguirre T, Van den Bosch L, Tilkin P, Cassiman JJ, Matthijs G. D90A heterozygosity in the SOD1 gene is associated with familial and apparently sporadic amyotrophic lateral sclerosis. Neurology. 1996;47(5):1336-1339.

66. Andersen P. Amyotrophic lateral sclerosis associated with mutations in the CuZn superoxide dismutase gene. Curr Neurol Neurosci Rep. 2006;6(1):37-46.
67. Gurney M, Pu H, Chiu A, et al. Motor neuron degeneration in mice that express a human $\mathrm{Cu}, \mathrm{Zn}$ superoxide dismutase mutation. Science. 1994;264(5166):1772-1775.

68. Reaume AG, Elliott JL, Hoffman EK, et al. Motor neurons in $\mathrm{Cu} / \mathrm{Zn}$ superoxide dismutase-deficient mice develop normally but exhibit enhanced cell death after axonal injury. Nat Genet. 1996;13(1):43-47.

69. Jonsson PA, Graffmo KS, Andersen PM, et al. Disulphide-reduced superoxide dismutase-1 in CNS of transgenic amyotrophic lateral sclerosis models. Brain. 2006;129 Pt 2:451-464.

70. Bruijn LI, Houseweart MK, Kato S, et al. Aggregation and motor neuron toxicity of an ALS-linked SOD1 mutant independent from wild-type SOD1. Science. 1998;281(5384):1851-1854.

71. Zetterstrom P, Stewart HG, Bergemalm D, et al. Soluble misfolded subfractions of mutant superoxide dismutase-1s are enriched in spinal cords throughout life in murine ALS models. Proc Natl Acad Sci USA. 2007;104(35):14157-14162.

72. Mackenzie IR, Rademakers R, Neumann M. TDP-43 and FUS in amyotrophic lateral sclerosis and frontotemporal dementia. Lancet Neurol. 2010;9(10):995-1007.

73. Tan CF, Eguchi H, Tagawa A, et al. TDP-43 immunoreactivity in neuronal inclusions in familial amyotrophic lateral sclerosis with or without SOD1 gene mutation. Acta Neuropathol. 2007;113(5):535-542.

74. Sreedharan J, Blair IP, Tripathi VB, et al. TDP-43 mutations in familial and sporadic amyotrophic lateral sclerosis. Science. 2008; 319(5870):1668-1672.

75. Kabashi E, Valdmanis PN, Dion P, et al. TARDBP mutations in individuals with sporadic and familial amyotrophic lateral sclerosis. Nat Genet. 2008;40(5):572-574.

76. Van Deerlin VM, Leverenz JB, Bekris LM, et al. TARDBP mutations in amyotrophic lateral sclerosis with TDP-43 neuropathology: a genetic and histopathological analysis. Lancet Neurol. 2008;7(5):409-416.

77. Yokoseki A, Shiga A, Tan CF, et al. TDP-43 mutation in familial amyotrophic lateral sclerosis. Ann Neurol. 2008;63(4):538-542.

78. Rutherford NJ, Zhang YJ, Baker M, et al. Novel mutations in TARDBP (TDP-43) in patients with familial amyotrophic lateral sclerosis. PLoS Genet. 2008;4(9):e1000193.

79. Buratti E, Dork T, Zuccato E, Pagani F, Romano M, Baralle FE. Nuclear factor TDP-43 and SR proteins promote in vitro and in vivo CFTR exon 9 skipping. EMBO J. 2001;20(7):1774-1784.

80. Strong MJ. The evidence for altered RNA metabolism in amyotrophic lateral sclerosis (ALS). J Neurol Sci. 2010;288(1-2):1-12.

81. Lagier-Tourenne C, Polymenidou M, Cleveland DW. TDP-43 and FUS/TLS: emerging roles in RNA processing and neurodegeneration. Hum Mol Genet. 2010;19(R1):R46-R64.

82. Arai T, Mackenzie IR, Hasegawa M, et al. Phosphorylated TDP-43 in Alzheimer's disease and dementia with Lewy bodies. Acta Neuropathol. 2009;117(2):125-136.

83. Armon C. Smoking may be considered an established risk factor for sporadic ALS. Neurology. 2009;73(20):1693-1698.

84. Weisskopf MG, McCullough ML, Calle EE, Thun MJ, Cudkowicz M, Ascherio A. Prospective study of cigarette smoking and amyotrophic lateral sclerosis. Am J Epidemiol. 2004;160(1):26-33.

85. Gallo V, Bueno-De-Mesquita HB, Vermeulen R, et al. Smoking and risk for amyotrophic lateral sclerosis: analysis of the EPIC cohort. Ann Neurol. 2009;65(4):378-385.

86. Fang F, Bellocco R, Hernan MA, Ye W. Smoking, snuff dipping and the risk of amyotrophic lateral sclerosis - a prospective cohort study. Neuroepidemiology. 2006;27(4):217-221.

87. Malek AM, Barchowsky A, Bowser R, et al. Environmental and occupational risk factors for amyotrophic lateral sclerosis: a case-control study. Neurodegener Dis. 2014;14:31-38.

88. Yu Y, Su FC, Callaghan BC, Goutman SA, Batterman SA, Feldman EL. Environmental risk factors and amyotrophic lateral sclerosis (ALS): a casecontrol study of ALS in Michigan. PLoS One. 2014;9(6):e101186.

89. Factor-Litvak P, Al-Chalabi A, Ascherio A, et al. Current pathways for epidemiological research in amyotrophic lateral sclerosis. Amyotroph Lateral Scler Frontotemporal Degener. 2013;14 Suppl 1:33-43. 
90. Ascherio A, Weisskopf MG, O'Reilly EJ, et al. Vitamin E intake and risk of amyotrophic lateral sclerosis. Ann Neurol. 2005;57(1):104-110.

91. Wang H, O'Reilly EJ, Weisskopf MG, et al. Vitamin E intake and risk of amyotrophic lateral sclerosis: a pooled analysis of data from 5 prospective cohort studies. Am J Epidemiol. 2011;173(6):595-602.

92. Veldink JH, Kalmijn S, Groeneveld GJ, et al. Intake of polyunsaturated fatty acids and vitamin $\mathrm{E}$ reduces the risk of developing amyotrophic lateral sclerosis. J Neurol Neurosurg Psychiatry. 2007;78(4):367-371.

93. Okamoto K, Kihira T, Kobashi G, et al. Fruit and vegetable intake and risk of amyotrophic lateral sclerosis in Japan. Neuroepidemiology. 2009;32(4):251-256.

94. Michal Freedman D, Kuncl RW, Weinstein SJ, Malila N, Virtamo J, Albanes D. Vitamin E serum levels and controlled supplementation and risk of amyotrophic lateral sclerosis. Amyotroph Lateral Scler Frontotemporal Degener. 2013;14(4):246-251.

95. de Bustos F, Jimenez-Jimenez FJ, Molina JA, et al. Cerebrospinal fluid levels of alpha-tocopherol in amyotrophic lateral sclerosis. $J$ Neural Transm. 1998;105(6-7):703-708.

96. Iwasaki Y, Ikeda K, Kinoshita M. Vitamin A and E levels are normal in amyotrophic lateral sclerosis. J Neurol Sci. 1995;132(2):193-194.

97. Graf M, Ecker D, Horowski R, et al. High dose vitamin E therapy in amyotrophic lateral sclerosis as add-on therapy to riluzole: results of a placebo-controlled double-blind study. J Neural Transm. 2005;112(5): 649-660.

98. Okamoto K, Kihira T, Kondo T, et al. Nutritional status and risk of amyotrophic lateral sclerosis in Japan. Amyotroph Lateral Scler Frontotemporal Degener. 2007;8(5):300-304.

99. Fitzgerald KC, O'Reilly EJ, Falcone GJ, et al. Dietary omega-3 polyunsaturated fatty acid intake and risk for amyotrophic lateral sclerosis. JAMA Neurol. 2014;71(9):1102-1110.

100. Beghi E, Pupillo E, Messina P, et al. Coffee and amyotrophic lateral sclerosis: a possible preventive role. Am J Epidemiol. 2011;174(9): $1002-1008$.

101. Morozova N, Weisskopf MG, McCullough ML, et al. Diet and amyotrophic lateral sclerosis. Epidemiology. 2008;19(2):324-337.

102. de Jong SW, Huisman MH, Sutedja NA, et al. Smoking, alcohol consumption, and the risk of amyotrophic lateral sclerosis: a population-based study. Am J Epidemiol. 2012;176(3):233-239.

103. Nelson LM, McGuire V, Longstreth WT Jr, Matkin C. Population-based case-control study of amyotrophic lateral sclerosis in western Washington State. I. Cigarette smoking and alcohol consumption. Am J Epidemiol. 2000;151(2):156-163.

104. Turner MR. Increased premorbid physical activity and amyotrophic lateral sclerosis: born to run rather than run to death, or a seductive myth? J Neurol Neurosurg Psychiatry. 2013;84(9):947.

105. Mattsson P, Lonnstedt I, Nygren I, Askmark H. Physical fitness, but not muscle strength, is a risk factor for death in amyotrophic lateral sclerosis at an early age. J Neurol Neurosurg Psychiatry. 2012;83(4):390-394.

106. Desport JC, Preux PM, Truong TC, Vallat JM, Sautereau D, Couratier P. Nutritional status is a prognostic factor for survival in ALS patients. Neurology. 1999;53(5):1059-1063.

107. Shimizu T, Nagaoka U, Nakayama Y, et al. Reduction rate of body mass index predicts prognosis for survival in amyotrophic lateral sclerosis: a multicenter study in Japan. Amyotroph Lateral Scler. 2012;13(4):363-366

108. Jawaid A, Murthy SB, Wilson AM, et al. A decrease in body mass index is associated with faster progression of motor symptoms and shorter survival in ALS. Amyotroph Lateral Scler. 2010;11(6):542-548.

109. Gallo V, Wark PA, Jenab M, et al. Prediagnostic body fat and risk of death from amyotrophic lateral sclerosis: the EPIC cohort. Neurology. 2013;80(9):829-838

110. O'Reilly EJ, Wang H, Weisskopf MG, et al. Premorbid body mass index and risk of amyotrophic lateral sclerosis. Amyotroph Lateral Scler Frontotemporal Degener. 2013;14(3):205-211.

111. Chio A, Benzi G, Dossena M, Mutani R, Mora G. Severely increased risk of amyotrophic lateral sclerosis among Italian professional football players. Brain. 2005;128 Pt 3:472-476.
112. Abel EL. Football increases the risk for Lou Gehrig's disease, amyotrophic lateral sclerosis. Percept Mot Skills. 2007;104(3 Pt 2): 1251-1254.

113. Chio A, Calvo A, Dossena M, Ghiglione P, Mutani R, Mora G. ALS in Italian professional soccer players: the risk is still present and could be soccer-specific. Amyotroph Lateral Scler. 2009;10(4): 205-209.

114. Lehman EJ, Hein MJ, Baron SL, Gersic CM. Neurodegenerative causes of death among retired National Football League players. Neurology. 2012;79(19):1970-1974

115. Felmus MT, Patten BM, Swanke L. Antecedent events in amyotrophic lateral sclerosis. Neurology. 1976;26(2):167-172.

116. Granieri E, Carreras M, Tola R, et al. Motor neuron disease in the province of Ferrara, Italy, in 1964-1982. Neurology. 1988;38(10): 1604-1608.

117. Roelofs-Iverson RA, Mulder DW, Elveback LR, Kurland LT, Molgaard CA. ALS and heavy metals: a pilot case-control study. Neurology. 1984;34(3):393-395.

118. Gregoire N, Serratrice G. [Risk factors in amyotrophic lateral sclerosis. Initial results apropos of 35 cases]. Rev Neurol (Paris). 1991;147(11): 706-713. French.

119. Savica R, Parisi JE, Wold LE, Josephs KA, Ahlskog JE. High school football and risk of neurodegeneration: a community-based study. Mayo Clin Proc. 2012;87(4):335-340.

120. Huisman MH, Seelen M, de Jong SW, et al. Lifetime physical activity and the risk of amyotrophic lateral sclerosis. J Neurol Neurosurg Psychiatry. 2013;84(9):976-981.

121. Al-Chalabi A, Leigh PN. Trouble on the pitch: are professional football players at increased risk of developing amyotrophic lateral sclerosis? Brain. 2005;128 Pt 3:451-453.

122. McKee AC, Gavett BE, Stern RA, et al. TDP-43 proteinopathy and motor neuron disease in chronic traumatic encephalopathy. J Neuropathol Exp Neurol. 2010;69(9):918-929.

123. Pupillo E, Messina P, Giussani G, et al. Physical activity and ALS. A European population-based, case-control study. Ann Neurol. 2014;75(5):708-716.

124. Roos PM. Studies on Metals in Motor Neuron Disease. Stockholm, Sweden: Institute of Environmental Medicine, Karolinska Institutet; 2013.

125. Gunnarsson LG, Bodin L. Epidemiologiskt påvisade samband mellan Amyotrofisk Lateral Skleros (ALS) och faktorer i arbetsmiljön. Gothenburg, Sweden: Occupational and Environmental Medicine, University of Gothenburg; In press.

126. Sutedja NA, Fischer K, Veldink JH, et al. What we truly know about occupation as a risk factor for ALS: a critical and systematic review. Amyotroph Lateral Scler. 2009;10(5-6):295-301.

127. Fang F, Quinlan P, Ye W, et al. Workplace exposures and the risk of amyotrophic lateral sclerosis. Environ Health Perspect. 2009;117(9): 1387-1392.

128. Beard JD, Kamel F. Military service, deployments, and exposures in relation to amyotrophic lateral sclerosis etiology and survival. Epidemiol Rev. October 31, 2014. [Epub ahead of print.]

129. Vergara X, Kheifets L, Greenland S, Oksuzyan S, Cho YS, Mezei G. Occupational exposure to extremely low-frequency magnetic fields and neurodegenerative disease: a meta-analysis. J Occup Environ Med. 2013;55(2):135-146.

130. Kheifets L, Bowman JD, Checkoway H, et al. Future needs of occupational epidemiology of extremely low frequency electric and magnetic fields: review and recommendations. Occup Environ Med. 2009;66(2):72-80

131. Feychting M, Jonsson F, Pedersen NL, Ahlbom A. Occupational magnetic field exposure and neurodegenerative disease. Epidemiology. 2003;14(4):413-419.

132. Vergara X, Mezei G, Kheifets L. Case-control study of occupational exposure to electric shocks and magnetic fields and mortality from amyotrophic lateral sclerosis in the US, 1991-1999. J Expo Sci Environ Epidemiol. June 11, 2014. [Epub ahead of print.] 
133. Fischer H, Vergara X, Yost M, Silva M, Lombardi D, Kheifets L. Developing data based, modeling and expert elicitation JEMs. Presented at the BioEM2014 Conference, Cape Town, South Africa, June 9-14, 2014.

134. Huss A, Spoerri A, Egger M, Kromhout H, Vermeulen R. Occupational exposure to magnetic fields and electric shocks and risk of ALS - the Swiss National Cohort. Amyotroph Lateral Scler Frontotemporal Degener. September 17, 2014. [Epub ahead of print.]

135. Zhou H, Chen G, Chen C, Yu Y, Xu Z. Association between extremely low-frequency electromagnetic fields occupations and amyotrophic lateral sclerosis: a meta-analysis. PLoS One. 2012;7(11):e48354.

136. Huss A, Spoerri A, Egger M, Röösli M; Swiss National Cohort Study. Residence near power lines and mortality from neurodegenerative diseases: longitudinal study of the Swiss population. Am J Epidemiol. 2009;169(2):167-175.

137. Marcilio I, Gouveia N, Pereira Filho ML, Kheifets L. Adult mortality from leukemia, brain cancer, amyotrophic lateral sclerosis and magnetic fields from power lines: a case-control study in Brazil. Braz $J$ Epidemiol. 2011;14(4):580-588.

138. Kamel F, Umbach DM, Hu H, et al. Lead exposure as a risk factor for amyotrophic lateral sclerosis. Neurodegener Dis. 2005;2(3-4): 195-201.

139. Deapen DM, Henderson BE. A case-control study of amyotrophic lateral sclerosis. Am J Epidemiol. 1986;123(5):790-799.

140. McGuire V, Longstreth WT Jr, Nelson LM, et al. Occupational exposures and amyotrophic lateral sclerosis. A population-based case-control study. Am J Epidemiol. 1997;145(12):1076-1088.

141. Gunnarsson LG, Bodin L, Soderfeldt B, Axelson O. A case-control study of motor neurone disease: its relation to heritability, and occupational exposures, particularly to solvents. Br J Ind Med. 1992;49(11): 791-798.

142. Campbell AM, Williams ER, Barltrop D. Motor neurone disease and exposure to lead. J Neurol Neurosurg Psychiatry. 1970;33(6): 877-885.

143. Pierce-Ruhland R, Patten BM. Repeat study of antecedent events in motor neuron disease. Ann Clin Res. 1981;13(2):102-107.

144. Gresham LS, Molgaard CA, Golbeck AL, Smith R. Amyotrophic lateral sclerosis and occupational heavy metal exposure: a case-control study. Neuroepidemiology. 1986;5(1):29-38.

145. Armon C, Kurland LT, Daube JR, O’Brien PC. Epidemiologic correlates of sporadic amyotrophic lateral sclerosis. Neurology. 1991;41(7): 1077-1084.

146. Chancellor AM, Slattery JM, Fraser H, Warlow CP. Risk factors for motor neuron disease: a case-control study based on patients from the Scottish Motor Neuron Disease Register. J Neurol Neurosurg Psychiatry. 1993;56(11):1200-1206.

147. Kamel F, Umbach DM, Lehman TA, et al. Amyotrophic lateral sclerosis, lead, and genetic susceptibility: polymorphisms in the delta-aminolevulinic acid dehydratase and vitamin $\mathrm{D}$ receptor genes. Environ Health Perspect. 2003;111(10):1335-1339.

148. Kamel F, Umbach DM, Munsat TL, Shefner JM, Hu H, Sandler DP. Lead exposure and amyotrophic lateral sclerosis. Epidemiology. 2002;13(3):311-319.

149. Albers K, Nelson L, Tanner C, et al. Lead exposure and amyotrophic lateral sclerosis in a Northern California population. Neuroepidemiology. 2009;33:74

150. $\mathrm{Hu} \mathrm{H}$, Payton M, Korrick S, et al. Determinants of bone and blood lead levels among community-exposed middle-aged to elderly men. The normative aging study. Am J Epidemiol. 1996;144(8):749-759.

151. Fang F, Kwee LC, Allen KD, et al. Association between blood lead and the risk of amyotrophic lateral sclerosis. Am J Epidemiol. 2010; 171(10):1126-1133.

152. Dobson AW, Erikson KM, Aschner M. Manganese neurotoxicity. Ann N Y Acad Sci. 2004;1012:115-128

153. Sjögren B, Iregren A, Frech W, et al. Effects on the nervous system among welders exposed to aluminium and manganese. Occup Environ Med. 1996;53(1):32-40.
154. Ellingsen DG, Konstantinov R, Bast-Pettersen R, et al. A neurobehavioral study of current and former welders exposed to manganese. Neurotoxicology. 2008;29(1):48-59.

155. Roos PM, Lierhagen S, Flaten TP, Syversen T, Vesterberg O, Nordberg M. Manganese in cerebrospinal fluid and blood plasma of patients with amyotrophic lateral sclerosis. Exp Biol Med (Maywood). 2012;237(7): 803-810.

156. Dusek P, Roos PM, Litwin T, Schneider SA, Flaten TP, Aaseth J. The neurotoxicity of iron, copper and manganese in Parkinson's and Wilson's diseases. J Trace Elem Med Biol. June 2, 2014. [Epub ahead of print.]

157. Kasarskis EJ, Tandon L, Lovell MA, Ehmann WD. Aluminum, calcium, and iron in the spinal cord of patients with sporadic amyotrophic lateral sclerosis using laser microprobe mass spectroscopy: a preliminary study. J Neurol Sci. 1995;130(2):203-208.

158. Kwan JY, Jeong SY, Van Gelderen P, et al. Iron accumulation in deep cortical layers accounts for MRI signal abnormalities in ALS: correlating 7 Tesla MRI and pathology. PLoS One. 2012; 7(4):e35241.

159. Kilness AW, Hichberg FH. Amyotrophic lateral sclerosis in a high selenium environment. J Am Med Assoc. 1977;237(26):2843-2844.

160. Vinceti M, Bonvicini F, Rothman KJ, Vescovi L, Wang F. The relation between amyotrophic lateral sclerosis and inorganic selenium in drinking water: a population-based case-control study. Environ Health . 2010;9:77

161. Vinceti M, Solovyev N, Mandrioli J, et al. Cerebrospinal fluid of newly diagnosed amyotrophic lateral sclerosis patients exhibits abnormal levels of selenium species including elevated selenite. Neurotoxicology. 2013;38:25-32.

162. Roos PM, Vesterberg O, Syversen T, Flaten TP, Nordberg M. Metal concentrations in cerebrospinal fluid and blood plasma from patients with amyotrophic lateral sclerosis. Biol Trace Elem Res. 2013;151(2):159-170.

163. Savettieri G, Salemi G, Arcara A, Cassata M, Castiglione MG, Fierro B. A case-control study of amyotrophic lateral sclerosis. Neuroepidemiology. 1991;10(5-6):242-245.

164. Morahan JM, Pamphlett R. Amyotrophic lateral sclerosis and exposure to environmental toxins: an Australian case-control study. Neuroepidemiology. 2006;27(3):130-135.

165. Weisskopf MG, Morozova N, O'Reilly EJ, et al. Prospective study of chemical exposures and amyotrophic lateral sclerosis. J Neurol Neurosurg Psychiatry. 2009;80(5):558-561.

166. Bonvicini F, Marcello N, Mandrioli J, Pietrini V, Vinceti M. Exposure to pesticides and risk of amyotrophic lateral sclerosis: a population-based case-control study. Ann Ist Super Sanita. 2010;46(3):284-287.

167. Das K, Nag C, Ghosh M. Familial, environmental, and occupational risk factors in development of amyotrophic lateral sclerosis. $N \mathrm{Am} \mathrm{J}$ Med Sci. 2012;4(8):350-355.

168. Kamel F, Umbach DM, Bedlack RS, et al. Pesticide exposure and amyotrophic lateral sclerosis. Neurotoxicology. 2012;33(3): 457-462.

169. Malek AM, Barchowsky A, Bowser R, Youk A, Talbott EO. Pesticide exposure as a risk factor for amyotrophic lateral sclerosis: a metaanalysis of epidemiological studies: pesticide exposure as a risk factor for ALS. Environ Res. 2012;117:112-119.

170. Cox PA, Banack SA, Murch SJ, et al. Diverse taxa of cyanobacteria produce beta-N-methylamino-L-alanine, a neurotoxic amino acid Proc Natl Acad Sci U S A. 2005;102(14):5074-5078.

171. Pablo J, Banack SA, Cox PA, et al. Cyanobacterial neurotoxin BMAA in ALS and Alzheimer's disease. Acta Neurol Scand. 2009;120(4): 216-225.

172. Jonasson S, Eriksson J, Berntzon L, et al. Transfer of a cyanobacterial neurotoxin within a temperate aquatic ecosystem suggests pathways for human exposure. Proc Natl Acad Sci U S A. 2010;107(20): 9252-9257.

173. Araoz R, Molgo J, Tandeau de Marsac N. Neurotoxic cyanobacterial toxins. Toxicon. 2010;56(5):813-828. 
174. Okumura H, Kurland LT, Waring SC. Amyotrophic lateral sclerosis and polio: is there an association? Ann N Y Acad Sci. 1995;753: 245-256.

175. Berger MM, Kopp N, Vital C, Redl B, Aymard M, Lina B. Detection and cellular localization of enterovirus RNA sequences in spinal cord of patients with ALS. Neurology. 2000;54(1):20-25.

176. Cermelli C, Vinceti M, Beretti F, et al. Risk of sporadic amyotrophic lateral sclerosis associated with seropositivity for herpesviruses and echovirus-7. Eur J Epidemiol. 2003;18(2):123-127.

177. Rowland LP. Ten central themes in a decade of ALS research. Adv Neurol. 1991;56:3-23.

178. Gardner MB. Retroviral leukemia and lower motor neuron disease in wild mice: natural history, pathogenesis, and genetic resistance. Adv Neurol. 1991;56:473-479.

179. Steele AJ, Al-Chalabi A, Ferrante K, Cudkowicz ME, Brown RH Jr, Garson JA. Detection of serum reverse transcriptase activity in patients with ALS and unaffected blood relatives. Neurology. 2005;64(3): 454-458.

180. Hadlock KG, Miller RG, Jin X, et al. Elevated rates of antibody reactivity to HML-2/HERV-K but not other endogenous retroviruses in ALS. Amyotroph Lateral Scler. 2004;5 Suppl 2:63.

181. Oluwole SO, Yao Y, Conradi S, Kristensson K, Karlsson H. Elevated levels of transcripts encoding a human retroviral envelope protein (syncytin) in muscles from patients with motor neuron disease. Amyotroph Lateral Scler. 2007;8(2):67-72.

182. Douville R, Liu J, Rothstein J, Nath A. Identification of active loci of a human endogenous retrovirus in neurons of patients with amyotrophic lateral sclerosis. Ann Neurol. 2011;69(1):141-151.

183. Alfahad T, Nath A. Retroviruses and amyotrophic lateral sclerosis. Antivir Res. 2013;99(2):180-187.

184. Chen H, Richard M, Sandler DP, Umbach DM, Kamel F. Head injury and amyotrophic lateral sclerosis. Am J Epidemiol. 2007;166(7): 810-816.

185. Pupillo E, Messina P, Logroscino G, et al. Trauma and amyotrophic lateral sclerosis: a case-control study from a population-based registry. Eur J Neurol. 2012;19(12):1509-1517.

186. Peters TL, Fang F, Weibull CE, Sandler DP, Kamel F, Ye W. Severe head injury and amyotrophic lateral sclerosis. Amyotroph Lateral Scler Frontotemporal Degener. 2013;14(4):267-272.

187. Desport JC, Preux PM, Magy L, et al. Factors correlated with hypermetabolism in patients with amyotrophic lateral sclerosis. Am J Clin Nutr. 2001;74(3):328-334.

188. Lekoubou A, Matsha TE, Sobngwi E, Kengne AP. Effects of diabetes mellitus on amyotrophic lateral sclerosis: a systematic review. $B M C$ Res Notes. 2014;7:171.

189. Turner MR, Goldacre R, Ramagopalan S, Talbot K, Goldacre MJ. Autoimmune disease preceding amyotrophic lateral sclerosis: an epidemiologic study. Neurology. 2013;81(14):1222-1225.

190. Mariosa D, Kamel F, Bellocco R, Ye W, Fang F. Association between diabetes and amyotrophic lateral sclerosis in Sweden. Eur J Neurol. In press.

191. Zheng Z, Sheng L, Shang H. Statins and amyotrophic lateral sclerosis: a systematic review and meta-analysis. Amyotroph Lateral Scler Frontotemporal Degener. 2013;14(4):241-245.

192. Dupuis L, Dengler R, Heneka MT, et al. A randomized, double blind, placebo-controlled trial of pioglitazone in combination with riluzole in amyotrophic lateral sclerosis. PLoS One. 2012;7(6):e37885.

193. Plun-Favreau H, Lewis PA, Hardy J, Martins LM, Wood NW. Cancer and neurodegeneration: between the devil and the deep blue sea. PLoS Genet. 2010;6(12):e1001257.

194. Tabares-Seisdedos R, Rubenstein JL. Inverse cancer comorbidity: a serendipitous opportunity to gain insight into CNS disorders. Nat Rev Neurosci. 2013;14(4):293-304.
195. Brain L, Croft PB, Wilkinson M. Motor neurone disease as a manifestation of neoplasm (with a note on the course of classical motor neurone disease). Brain. 1965;88(3):479-500.

196. Mitchell DM, Olczak SA. Remission of a syndrome indistinguishable from motor neurone disease after resection of bronchial carcinoma. BMJ. 1979;2(6183):176-177.

197. Sadot E, Carluer L, Corcia P, Delozier Y, Levy C, Viader F. Breast cancer and motor neuron disease: clinical study of seven cases. Amyotroph Lateral Scler. 2007;8(5):288-291.

198. Chio A, Brignolio F, Meineri P, Rosso MG, Tribolo A, Schiffer D. Motor neuron disease and malignancies: results of a population-based study. J Neurol. 1988;235(6):374-375.

199. Freedman DM, Travis LB, Gridley G, Kuncl RW. Amyotrophic lateral sclerosis mortality in 1.9 million US cancer survivors. Neuroepidemiology. 2005;25(4):176-180.

200. Fois AF, Wotton CJ, Yeates D, Turner MR, Goldacre MJ. Cancer in patients with motor neuron disease, multiple sclerosis and Parkinson's disease: record linkage studies. J Neurol Neurosurg Psychiatry. 2010;81(2):215-221.

201. Freedman DM, Curtis RE, Daugherty SE, Goedert JJ, Kuncl RW, Tucker MA. The association between cancer and amyotrophic lateral sclerosis. Cancer Causes Control. 2013;24(1):55-60.

202. Baade PD, Fritschi L, Freedman DM. Mortality due to amyotrophic lateral sclerosis and Parkinson's disease among melanoma patients. Neuroepidemiology. 2007;28(1):16-20.

203. Seelen M, van Doormaal PT, Visser AE, et al. Prior medical conditions and the risk of amyotrophic lateral sclerosis. J Neurol. 2014;261(10): 1949-1956.

204. Fang F, Al-Chalabi A, Ronnevi LO, et al. Amyotrophic lateral sclerosis and cancer: a register-based study in Sweden. Amyotroph Lateral Scler Frontotemporal Degener. 2013;14(5-6):362-368.

205. Freedman DM, Wu J, Daugherty SE, Kuncl RW, Enewold LR, Pfeiffer RM. The risk of amyotrophic lateral sclerosis after cancer in US elderly adults: a population-based prospective study. Int J Cancer. 2014;135(7):1745-1750.

206. Sreedharan J, Brown RH Jr. Amyotrophic lateral sclerosis: problems and prospects. Ann Neurol. 2013;74(3):309-316.

207. Eisen A. Amyotrophic lateral sclerosis: a 40-year personal perspective. J Clin Neurosci. 2009;16(4):505-512.

208. Ismail A, Cooper-Knock J, Highley JR, et al. Concurrence of multiple sclerosis and amyotrophic lateral sclerosis in patients with hexanucleotide repeat expansions of C9ORF72. J Neurol Neurosurg Psychiatry. 2013;84(1):79-87.

209. Xi Z, Yunusova Y, van Blitterswijk M, et al. Identical twins with the C9orf72 repeat expansion are discordant for ALS. Neurology. 2014;83(16):1476-1478.

210. Mahley RW, Huang Y. Apolipoprotein E sets the stage: response to injury triggers neuropathology. Neuron. 2012;76(5):871-885.

211. Kakalacheva K, Lunemann JD. Environmental triggers of multiple sclerosis. FEBS Lett. 2011;585(23):3724-3729.

212. Goldman SM, Kamel F, Ross GW, et al. Head injury, alpha-synuclein Rep1, and Parkinson's disease. Ann Neurol. 2012;71(1):40-48.

213. Al-Chalabi A, Hardiman O. The epidemiology of ALS: a conspiracy of genes, environment and time. Nat Rev Neurol. 2013;9(11): $617-628$.

214. Swinnen B, Robberecht W. The phenotypic variability of amyotrophic lateral sclerosis. Nat Rev Neurol. 2014;10(11):661-670.

215. Zheng W, Aschner M, Ghersi-Egea JF. Brain barrier systems: a new frontier in metal neurotoxicological research. Toxicol Appl Pharmacol. 2003;192(1):1-11. 


\section{Publish your work in this journal}

Clinical Epidemiology is an international, peer-reviewed, open access, online journal focusing on disease and drug epidemiology, identification of risk factors and screening procedures to develop optimal preventative initiatives and programs. Specific topics include: diagnosis, prognosis, treatment, screening, prevention, risk factor modification,

Submit your manuscript here: http://www.dovepress.com/clinical-epidemiology-journal

\section{Dovepress}

systematic reviews, risk \& safety of medical interventions, epidemiology \& biostatistical methods, and evaluation of guidelines, translational medicine, health policies \& economic evaluations. The manuscript management system is completely online and includes a very quick and fair peer-review system, which is all easy to use. 